\title{
Towards Participatory Governance in Overcoming Climate Change: A Study of Stakeholders' Participation in Forest Governance in Indonesia
}

\author{
Auradian Marta ${ }^{\circ}$ \\ Department of Government Studies, Universitas Riau, Pekanbaru, Indonesia
}

\begin{tabular}{|c|c|}
\hline ARTICLE INFORMATION & A B S T R A C T \\
\hline $\begin{array}{l}\text { Received: July 26, } 2021 \\
\text { Revised: September 23, } 2021 \\
\text { Accepted: October 18, } 2021 \\
\text { Available online: October 31, } 2021\end{array}$ & \multirow{5}{*}{$\begin{array}{l}\text { One of the Sustainable Development Goals (SDGs) objectives is to overcome climate change by preventing } \\
\text { deforestation and forest degradation. Indonesia is a country with a high rate of deforestation and forest } \\
\text { degradation. Therefore, this study aims to analyze stakeholders' participation in addressing deforestation and } \\
\text { forest degradation in transforming forest governance in Indonesia to achieve SDGs. This study applies a } \\
\text { qualitative approach, and the data are collected throughinterviews and examination of documents. The collected } \\
\text { data are analyzed by interactive models and theories relevant to the study. The findings of this study indicate } \\
\text { that there has been a change in forest governance in Indonesia from top-down into bottom-up forest governance, } \\
\text { prioritizing the principles of participatory governance. Indonesia's current forest governance system has } \\
\text { involved multi-stakeholders in achieving transparent, accountable, and constitutional forest governance, } \\
\text { favouring public interest. Furthermore, local, national, and international Civil Society Organizations (CSOs) } \\
\text { also play a role and synergize with the government, private sector, community, and indigenous peoples to } \\
\text { encourage improvements in forest governance in Indonesia. Finally, the business community plays a role in } \\
\text { sustainable forest management to maintain forest resources and ecosystems. It can be concluded that forest } \\
\text { management in Indonesia has led to participatory governance by involving stakeholders, leading to a } \\
\text { distribution of roles, authorities, and responsibilities in forest governance in Indonesia. }\end{array}$} \\
\hline KEYWORDS & \\
\hline $\begin{array}{l}\text { Participatory Governance; } \\
\text { Climate Change }\end{array}$ & \\
\hline CORRESPONDENCE & \\
\hline E-mail: auradian_unri@yahoo.com & \\
\hline
\end{tabular}

\section{PENDAHULUAN}

Sustainable Development Goals (SDGs) saat ini merupakan agenda yang telah diadopsi dan dilaksanakan di berbagai negara termasuk Indonesia. SDGs adalah langkah lebih lanjut dari Tujuan Pembangunan Milenium (MDGs) yang disepakati dalam 200 tahun terakhir dan telah berakhir pada tahun 2015. MDGs kemudian diganti dengan SDGs sebagai bentuk peningkatan dan pengembangan program sebelumnya. Konsep pembangunan berkelanjutan menurut Komisi Brundtland adalah kemampuan untuk membuat pembangunan berkelanjutan untuk memastikan bahwa ia memenuhi kebutuhan saat ini tanpa mengorbankan kemampuan generasi mendatang untuk memenuhi kebutuhan mereka sendiri (Robert W. Kates, Thomas M. Parris, 2005).

SDGs penting untuk dilaksanakan karena ada tiga dimensi yang menjadi fokus perhatian, yaitu pembangunan ekonomi, kelestarian lingkungan, dan inklusi sosial (Sachs, 2012). Sachs (2012) lebih lanjut menyatakan bahwa untuk mencapai tujuan SDGs ini membutuhkan adanya tata kelola yang baik di semua tingkatan, yaitu lokal, nasional, regional dan global. Oleh karena itu, SDGs yang rencananya akan dilaksanakan dari tahun 2015 hingga 2030, merupakan tujuan bersama yang akan diwujudkan bersama. Selanjutnya, menurut Monkelbaan(2019) dalam mewujudkan SDGs membutuhkan komitmen seluruh pemangku kepentingan dengan(l) membentuk dan mengkoordinasikan kepentingan berbagai pemangku kepentingan lintas isu; (2) memobilisasi tindakan kolektif berdasarkan visi bersama dan metanarrative pada pembangunan dan keberlanjutan; dan (3) membantu menciptakan pemahaman global bersama tentang isu-isu dan masalah yang dihadapi.
Salah satu isu penting dalam SDGs ini adalah mengatasi perubahan iklim. Indonesia memiliki kontribusi besar terhadap perubahan iklim dunia. Hal ini karena Indonesia merupakan negara yang memiliki sumber daya hutan yang luas, yaitu sekitar 109 juta hektar pada tahun 2003 (WWF, 2009). Namun, hutan di Indonesia semakin berkurang setiap harinya. Deforestasi dan degradasi hutan di Indonesia semakin meluas. Berikut pada gambar 1 data deforestasi di Indonesia dari tahun 1990-2012.

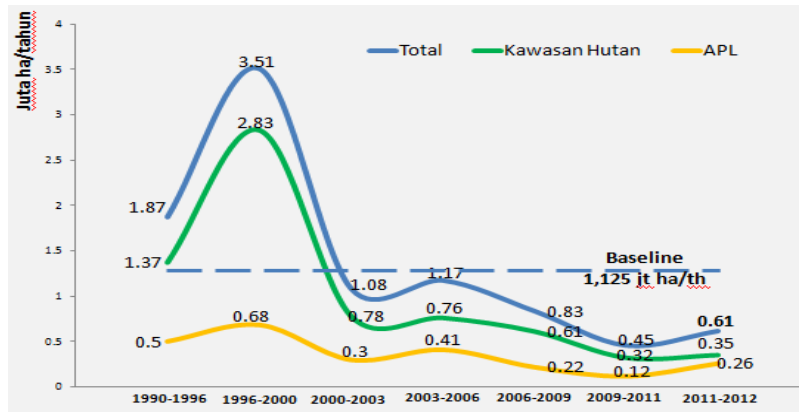

Gambar 1 Data deforestasi di Indonesia, periode 1990-2012 Sumber: Kementerian Lingkungan Hidup dan Kehutanan (2014)

Akibat dari deforestasi dan degradasi hutan di Indonesia menyebabkan krisis iklim dan bencana lingkungan serta merusak ekosistem kehidupan. Tingkat deforestasi tertinggi terjadi 3 daerah yakni di Kalimantan dengan 41.500 hektare, Nusa Tenggara 21.300 hektare, dan Sumatera 17.900 hektare.

Studi tata kelola hutan di Indonesia telah dilakukan oleh beberapa sarjana dengan berbagai studi fokus seperti yang menganalisis REDD + (Agung, Galudra, Van Noordwijk, \& 
Maryani, 2014; Astuti \& McGregor, 2015; Hein, J., \& Faust, 2014; dan Mulyani, M., \& Jepson, 2013) desentralisasi dan tata kelola hutan (Bullinger \& Haug, 2012; Gallemore, Di Gregorio, Moeliono, Brockhaus, \& Dini Prasti, 2015; Sahide, M. A. K., Supratman, S., Maryudi, A., Kim, Y. S., \& Giessen, 2016; dan Wollenberg et al., 2006), dan menganalisis konflik dalam tata kelola hutan (Asihing, 2014; Fisher, Kim, Latifah, \& Makarom, 2017; Y Yasmi, Guernier, Colfer, \& Guenier, 2009; dan Yurdi Yasmi \& Schanz, 2010).

Perbedaan antara penelitian ini dan penelitian sebelumnya adalah bahwa penelitian ini mencoba untuk mengekspresikan upaya untuk mengatasi perubahan iklim dengan tata kelola hutan menggunakan pendekatan tata kelola partisipatif. Menurut Jessop (2003), tata kelola partisipatif adalah cara penting untuk mendefinisikan tujuan dengan memperkuat motivasi dan memobilisasi kapasitas untuk refleksi diri, pengaturan diri, dan koreksi diri. Sementara itu, Fung, A \& Wright (2003) berpendapat bahwa pemerintahan partisipatif adalah bentuk pemerintahan kolaboratif yang secara khas menggabungkan partisipasi populer, pengambilan keputusan terdesentralisasi, fokus praktis, pertimbangan dan keterlibatan berkelanjutan, dan kerja sama antara pihak dan kepentingan yang sering menemukan diri mereka pada pertanyaan yang berlawanan dan sosial. Berdasarkan penjelasan ini, jelas bahwa kolaborasi dari para pemangku kepentingan mutlak diperlukan untuk tata kelola partisipatif.

Oleh karena itu, tulisan ini bertujuan untuk menjelaskan bagaimana para pemangku kepentingan berpartisipasi dalam mengatasi deforestasi dan degradasi hutan dalam konteks transformasi tata kelola hutan di Indonesia untuk mewujudkan Tujuan Pembangunan Berkelanjutan (SDGs). Menilik partisipasi stakeholders sebelumnya masih belum terjadi sinergitas dan terintegrasi sehingga belum terjalin kolaborasi yang baik. Pentingnya penelitian ini dilakukan dalam rangka memahami upaya yang dilakukan para pemangku kepentingan dalam membangun tata kelola hutan yang baik di Indonesia sehingga masalah degradasi dan deforestasi dapat diminimalisir.

\section{METODE}

Penelitian ini menggunakan metode kualitatif. Menurut Bryman (2012), penelitian kualitatif adalah strategi penelitian yang biasanya menekankan daripada kuantifikasi dalam pengumpulan dan analisis data. Berg (2001) menjelaskan bahwa penelitian kualitatif dengan benar menetapkan jawaban atas pertanyaan dari memeriksa berbagai pengaturan sosial dan individu yang menghuni pengaturan ini. Selanjutnya, pengumpulan data dalam penelitian ini menggunakan teknik yang diusulkan oleh Creswell (2014), yaitu dengan wawancara kualitatif dan dokumen kualitatif. Wawancara ini adalah pendapat informan atau peserta pada fokus penelitian yang diteliti. Lokus penelitian ini adalah Indonesia dengan mendeskripsikan dan menganalisis beberapa kasus seperti di Provinsi Riau, Papua, dan Kalimantan. Khusus mengenai wawancara dilakukan pada informan kunci yakni Dirjen Perhutanan Sosial dan Kemitraan Lingkungan Hidup KLHK, dan Dinas Kehutanan Provinsi Riau. Sementara itu, informan tambahan dalam studi ini adalah Lembaga Adat Melayu Riau, Walhi Riau dan anggota Pansus Monitoring lahan DPRD Provinsi Riau. Sementara itu, studi dokumen berasal dari buku, artikel di jurnal, laporan, dokumen pemerintah, dan artikel di media massa dan media online. Kemudian analisis data dalam penelitian ini menggunakan model interaktif. Houghton, Murphy, Shaw, \& Casey (2015) menyatakan bahwa model interaktif dapat dijelaskan dalam gambar 2 berikut:

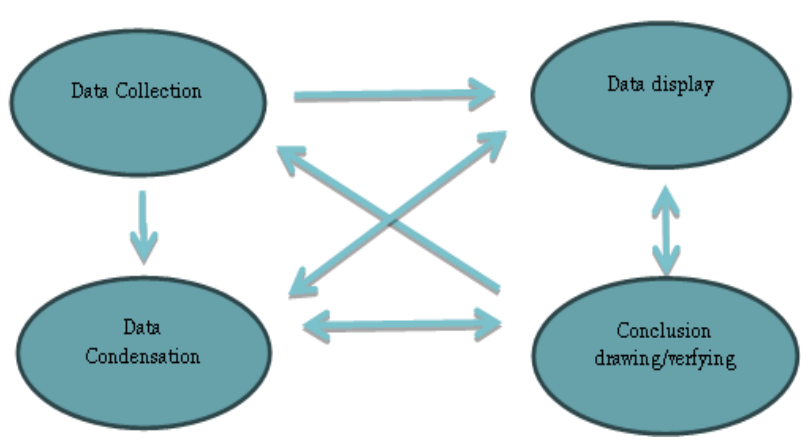

Gambar 2. Model Interaktif

Sumber: Miles, Hubermane Saldaña (2014)

Data yang dikumpulkan baik dari wawancara maupun data dokumen dari informan penelitian akan diringkas dan ditampilkan. Kondensasi data ini mengacu pada proses pemilihan, pemfokusan, penyederhanaan, abstrak, dan / atau mengubah data dari catatan lapangan, transkrip wawancara, dokumen, dan dokumen empiris lainnya. Kegiatan berikutnya adalah menampilkan data yang berarti mengumpulkan informasi dan menampilkannya secara sistematis. Pengumpulan data yang dikumpulkan, dipilih dan ditampilkan secara sistematis dan terorganisir berguna untuk kegiatan lebih lanjut dalam analisis data, yaitu memverifikasi dan menggambarkan data dengan interpretasi berdasarkan teori yang relevan.

\section{HASIL DAN PEMBAHASAN}

Tujuan dan tata kelola Pembangunan Berkelanjutan terkait dengan dua hal, pertama, tata kelola dan kebutuhan kelembagaan untuk mendukung tindakan, implementasi, dan peninjauan SDGs, dan kedua, perbaikan tata kelola yang bekerja pada SDGs dapat mempromosikan dan mengejar (Monkelbaan, 2019). Sementara itu, Kooiman (2003) kemudian menjelaskan tata kelola pemerintahan, yang disebut pemerintahan sosial-politik, yaitu 'kolektif'. Kolektif tidak dalam arti bahwa perawatan dan pengembangan kegiatan ini dipandang sebagai tugas publik ('negara'), tanggung jawab sektor swasta ('pasar'), atau sektor ketiga ('masyarakat sipil') Secara terpisah, tetapi sebagai serangkaian tanggung jawab bersama. Jadi untuk mengatasi perubahan iklim yang merupakan tantangan global membutuhkan banyak pemangku kepentingan untuk terlibat (Fröhlich, J., \& Knieling, n.d.).

\section{Keterlibatan Masyarakat dan Masyarakat Adat dalam Tata Kelola Hutan}

Kebijakan tata kelola hutan di Indonesia Selama periode Orde Baru itu dikendalikan secara terpusat oleh Pemerintah Pusat. Pengelolaan hutan yang berpusat pada pemerintah ini menyebabkan penyalahgunaan wewenang dalam perizinan kehutanan yang mengakibatkan deforestasi yang luas dan degradasi hutan selama Orde Baru. Reformasi yang berlangsung pada tahun 1998 memberikan harapan untuk reformasi dalam pengelolaan hutan di Indonesia. Pada awal reformasi UU, No. 41 tahun 1999 didirikan yang memberikan kewenangan dalam 
pengelolaan hutan tidak hanya kepada Pemerintah Pusat, tetapi juga kewenangan Pemerintah Daerah.

Tidak hanya kewenangan Pemerintah Daerah, tata kelola hutan di Indonesia kini melibatkan partisipasi dari masyarakat dan masyarakat adat. Salah satu instrumen kebijakan yang menegaskan keterlibatan masyarakat dan masyarakat adalah kebijakan terkait perhutanan sosial. Pada prinsipnya, kebijakan perhutanan sosial ini mengadopsi prinsip pengelolaan hutan berbasis masyarakat (CBFM). CBFM dapat menggunakan bentuk praktik kehutanan yang disetujui pemerintah yang melibatkan pengguna hutan langsung dalam proses pengambilan keputusan umum dan kegiatan kehutanan, yang membutuhkan otonomi pengambilan keputusan untuk mengarahkan pengguna hutan dalam menetapkan tujuan, kontrol lokal dalam pengelolaan dan pemanfaatan hutan, dan kepemilikan manfaat hutan (Nath, T. K., Jashimuddin, M., \& Inoue, 2016). Kebijakan perhutanan sosial ini sudah ada sejak kepemimpinan Susilo Bambang Yudhoyono, yakni pada 2007. Penerapan kebijakan perhutanan sosial ini menjadi bukti bahwa tata kelola hutan kini mulai berorientasi pada masyarakat dan masyarakat adat. Peraturan Menteri Lingkungan Hidup dan Kehutanan No. P.83/MENLHK/SETJEN/KUM.1/10/2016 tentang Perhutanan Sosial memberikan akses dan hak kepada masyarakat dan masyarakat adat untuk mengelola hutan.

Hutan yang dapat dikelola melalui skema perhutanan sosial ini adalah sebagai berikut: (1) Hutan Desa (HD) adalah hutan negara yang dikelola oleh desa dan digunakan untuk kesejahteraan desa, jika permohonan disetujui, maka hak pengelolaan hutan desa (HPHD) akan dikeluarkan sebagai bentuk pengakuan pemerintah terhadap masyarakat untuk mengelola hutan dan fungsi hutan yang dapat menjadi hutan desa adalah hutan produksi dan hutan lindung; (2) Hutan Masyarakat $(\mathrm{HKm})$ yaitu hutan negara yang pemanfaatannya terutama ditujukan untuk memberdayakan masyarakat, dan jika disetujui, aplikasi tersebut kemudian akan mendapatkan izin usaha pemanfaatan hutan masyarakat (IUPHKm). Fungsi hutan yang dapat menjadi objek HKm adalah hutan produksi dan hutan lindung; (3) Hutan Tanaman Masyarakat (HTR) adalah perkebunan di hutan produksi yang dibangun oleh kelompok masyarakat untuk meningkatkan potensi dan kualitas hutan produksi dengan menerapkan silvikultur untuk memastikan kelestarian sumber daya hutan. Pemohon yang dikabulkan permohonan akan mendapatkan izin usaha pemanfaatan hasil hutan kayu masyarakat (IUP HHK-HTR); (4) Kemitraan, yaitu kerja sama antara masyarakat lokal dan pengelola hutan, pemegang izin pemanfaatan jasa kehutanan/hutan, penggunaan izin hutan, atau pemegang izin usaha hasil hutan primer. Kemitraan atau kerja sama ini dapat dilakukan di semua jenis hutan, baik itu hutan produksi, hutan lindung atau hutan konservasi; dan (5) Hutan Adat, yaitu hutan yang tidak berada di dalam kawasan hutan negara tetapi berada di dalam hutan yang tepat. Hutan adat adalah hutan yang berada di dalam wilayah masyarakat adat. Artinya pengelolaan hutan penuh berada di tangan masyarakat adat (Firdaus, 2018).

Kebijakan perhutanan sosial ini merupakan bentuk reformasi tenurial di Indonesia dengan memperkuat partisipasi masyarakat dan masyarakat adat dalam pengelolaan hutan. Pemerintah periode 2014-2019 menargetkan 12,7 juta hektar hutan dalam skema perhutanan sosial. Realisasi program Perhutanan Sosial ini umumnya meningkat selama tiga tahun terakhir (2015 hingga 2018). Selama periode ini, izin yang dikeluarkan kepada masyarakat untuk mengelola hutan mencapai 1.558.453,58 hektar, yang terdiri dari 969.215,18 hektar untuk kawasan Hutan Desa (HD), 337.142,51 hektar untuk area HKm, 99.709,87 hektar untuk daerah tersebut. HTR; 102.000,08 hektar untuk hutan kemitraan, 22.435,59 hektar untuk luas Izin Pemanfaatan Perhutanan Sosial (IPHPS); dan seluas 27.950.3493 hektar untuk Hutan Adat (Forestry, 2018).

Melalui skema pengelolaan hutan berbasis masyarakat ini memberikan manfaat bagi lingkungan global seperti mengurangi deforestasi dan melestarikan keanekaragaman hayati, dan meningkatkan kesejahteraan masyarakat lokal (Bowler et al., 2012). Argumen Bowler (2012) secara empiris dibuktikan dengan penerapan kebijakan perhutanan sosial di mana masyarakat mendapatkan akses pengelolaan hutan melalui perizinan sehingga dapat mengurangi kemiskinan di sekitar wilayah perhutanan sosial di Indonesia. Dewi (2018) menyatakan bahwa adanya kebijakan perhutanan sosial akan meningkatkan kapasitas petani melalui kerja sama dengan koperasi dan mitra usaha lainnya sehingga kesejahteraan petani dapat terwujud sekaligus melestarikan hutan.

Reformasi tenurial melalui skema perhutanan sosial ini merupakan bentuk konkret Dari Pengelolaan Hutan Berbasis Masyarakat (CBFM). Keterlibatan masyarakat dan masyarakat adat dalam pengelolaan merupakan bentuk inovasi pemberdayaan untuk mengatasi perubahan iklim. Tanggung jawab pengelolaan hutan saat ini tidak hanya dikendalikan oleh pemerintah, tetapi juga masyarakat dan masyarakat adat juga memiliki hak dan kewajiban dalam melindungi lingkungan hutan. Hal ini dapat diwujudkan dengan memberikan hak pengelolaan hutan kepada masyarakat dan masyarakat adat sehingga berperan aktif dalam upaya pengelolaan hutan berkelanjutan.

\section{Jaringan Masyarakat Sipil dalam Tata Kelola Hutan Berkelanjutan}

Keterlibatan Civil Society Organizations (CSO) saat ini sangat intens dan aktif dalam mewujudkan hutan lestari. Hal ini menunjukkan bahwa telah terjadi reformasi dalam pengelolaan hutan yang sebelumnya dinyatakan sentris. Berbagai hal telah dilakukan oleh CSO baik dari dalam negeri, maupun yang berasal dari luar negeri. Koalisi dan kerja sama antara CSO telah melahirkan berbagai program dan kebijakan yang mendukung upaya pengelolaan hutan berkelanjutan. Salah satu bukti empiris program yang cukup signifikan dalam mengubah paradigma pengelolaan hutan di Indonesia adalah program SETAPAK (Selamatkan Hutan dan Lahan melalui Perbaikan Tata Kelola). Program tata kelola lingkungan Setapak Dari Asia Foundation bekerja untuk meningkatkan tata kelola hutan dan lahan di Indonesia. Program ini mempromosikan tata kelola hutan dan lahan yang baik sangat penting untuk mengurangi emisi gas rumah kaca yang didistribusikan secara berkelanjutan dan merata. Program ini merupakan tahap pertama dari 2012 hingga Juli 2015, dan sekarang tahap kedua berjalan hingga Maret 2020. Program SETAPAK saat ini bekerja dengan lebih dari 60 Organisasi Masyarakat Sipil (CSO) (SETAPAK, 2018).

Keberhasilan program SETAPAK yang dilakukan oleh jaringan CSO pada tahap 2 telah disampaikan di Forestival 4 sebagai berikut: 
1. Membuat 239 kebijakan terkait Izin Perhutanan Sosial, Transparansi, Perencanaan Kawasan (RTRW) dan kebijakan terkait, penganggaran, kebijakan mediasi konflik, Moratorium, hak-hak masyarakat tradisional, dan lain-lain untuk membenahi Pengelolaan Hutan dan Lahan.

2. $16 \%$ izin yang melanggar aturan telah dihapus secara nasional melalui Korsup Minerba (Koordinator dan Pengawasan Sektor Mineral dan Batubara) KPK.

3. Berkontribusi $13 \%$ terhadap 1,72 juta pendapatan di Perhutanan Sosial secara nasional. Dimana 222.385 hektar telah disetujui untuk dikelola oleh warga melalui berbagai Rencana Perhutanan Sosial, serta 20 proposal tambahan untuk mendapatkan Izin Perhutanan Sosial telah diajukan (SETAPAK, 2018)

Sementara itu, aliansi CSO di tingkat lokal dan nasional berusaha untuk mengadvokasi kebijakan yang ditetapkan oleh Pemerintah dan Pemerintah Daerah. Huma dan jaringan CSO mengadvokasi kebijakan di tingkat nasional dan regional. Pada advokasi kebijakan tingkat nasional dilakukan terhadap RUU Masyarakat Adat, Rencana Perdagangan UU Kehutanan, Judicial Review Perpres 88/2017, dan Judicial Review PP Nomor 24/2018. Sementara itu, advokasi kebijakan daerah yang dilakukan pada tahun 2018 adalah penyusunan rancangan peraturan gubernur tanah adat di Provinsi Riau, penyusunan masyarakat hukum adat di Kabupaten Paser, Kalimantan Timur, penyusunan Peraturan Provinsi masyarakat adat Papua Barat, dan menyusun hukum adat di Teluk Bintuni Papua Barat (HuMa, 2018).

Selain mengadvokasi kebijakan, koalisi CSO juga mengawasi pengembangan dan pengelolaan hutan di Indonesia. Pemantauan yang dilakukan oleh aliansi CSO bertujuan untuk memastikan bahwa pengembangan sektor kehutanan bermanfaat bagi kesejahteraan masyarakat dan sebagai upaya penyelamatan hutan dan lingkungan. Pengawasan yang dilakukan oleh CSO juga diikuti dengan mendorong upaya penegakan hukum terhadap semua kegiatan perusakan lingkungan, terutama yang dilakukan oleh korporasi. Jikalahari, Walhi Riau, dan WWF Riau telah melakukan investigasi dan melaporkan sebanyak 49 korporasi yang terindikasi terlibat dalam kebakaran hutan dan lahan di Provinsi Riau (Forest, 2016). Satu hal yang perlu diperkuat dalam tata kelola hutan partisipatif adalah melibatkan multi pemangku kepentingan dalam penegakan hukum terhadap segala bentuk pelanggaran dalam pengelolaan hutan. Penegakan hukum bekerja untuk mempromosikan supremasi hukum dan mencegah kegiatan hutan ilegal dan membantu mencegah korupsi dan pencucian uang dan pencucian uang di sektor kehutanan. Korupsi dalam produk kehutanan dan sektor industri berbasis lahan membuat kerugian besar pada pendapatan negara. Pada tahun 2012, kerugian negara diperkirakan mencapai 273.924 triliun menurut rilis Kementerian Kehutanan (Mongabay, 2019).

Terakhir, peran CSO dalam berpartisipasi dalam menyelesaikan konflik kehutanan yang terjadi di berbagai daerah di Indonesia. Penyelesaian konflik kehutanan dilakukan oleh berbagai pihak tidak hanya pemerintah tetapi juga keterlibatan LSM dan masyarakat setempat. Contoh keterlibatan CSO dalam penyelesaian konflik hutan yang terjadi di Kabupaten Berau dan Kapuas Hulu, Kalimantan. LSM seperti Kelompok Kerja Penguasaan Lahan Hutan (WGT) dan Program Hutan dan Perubahan Iklim (FORCLIME) telah bekerja sama dengan para pemangku kepentingan seperti pemerintah daerah, sektor swasta, pemimpin tradisional, dan masyarakat setempat, dalam menyelesaikan konflik kehutanan di Kalimantan. Tidak hanya itu, tetapi juga mediasi dengan pihak-pihak yang terlibat dalam konflik, LSM ini juga berkoordinasi dengan Kementerian Lingkungan Hidup dan Kehutanan agar penyelesaian konflik dapat diselesaikan (FORCLIME, 2016). Selanjutnya, koalisi LSM yaitu Walhi Riau, Serikat Petani Riau, PRD Riau, JMGR, Jikalahari, Greenpeace, Kabut, TII Riau, Scale Up, dan Rumah Pohon memiliki kontribusi terhadap penyelesaian konflik kehutanan di Provinsi Riau khususnya konflik di Pulau Padang (Saturi, 2012).

Jaringan CSO di tingkat lokal, nasional dan internasional telah berkontribusi pada pengelolaan hutan berkelanjutan di Indonesia. CSO telah bersinergi dengan pemerintah, akademisi, tokoh adat, sektor swasta, dan masyarakat dalam mengejar tata kelola hutan yang baik di Indonesia. Menurut Heinelt (2010) dalam pemerintahan partisipatif, peran masyarakat sipil adalah menjadi intermediasi kepentingan. Inilah yang dilakukan CSO dengan memberikan bantuan kepada masyarakat, advokasi kebijakan, pengawasan, penegakan hukum, dan penyelesaian konflik. Strategi ini diterapkan oleh CSO dan koalisi-nya untuk mencapai pengelolaan hutan berkelanjutan dan membawa manfaat bagi masyarakat.

\section{Kontribusi Swasta untuk Mewujudkan Tata Kelola Hutan Berkelanjutan}

Kemitraan dalam tata kelola hutan diperlukan tanpa kecuali untuk sektor swasta. Peran sektor swasta sangat penting dalam mewujudkan tata kelola hutan yang baik karena selama ini perusahaan telah berkontribusi terhadap deforestasi dan degradasi hutan di Indonesia. Sebagai bentuk kepedulian dari pihak swasta dalam mengurangi dampak perubahan iklim, diperlukan transformasi tata kelola hutan. Upaya yang dilakukan oleh sektor swasta untuk berpartisipasi dalam mewujudkan pengelolaan hutan berkelanjutan adalah dengan mengikuti standar atau sertifikasi dalam mendukung kebijakan nol deforestasi. Beberapa bentuk sertifikasi diikuti oleh perusahaan, yaitu Roundtable on Sustainable Palm Oil (RSPO) dan Indonesian Sustainable Palm Oil (ISPO).

Roundtable on Sustainable Palm Oil (RSPO) adalah standar global yang dirilis pada tahun 2007. Pada tahun 2013 revisi prinsip-prinsip RSPO wajib bagi perusahaan untuk disertifikasi. Prinsip-prinsip ini adalah (1) Komitmen terhadap transparansi, (2) Kepatuhan terhadap hukum dan peraturan yang berlaku, (3) Komitmen terhadap kelangsungan hidup ekonomi dan keuangan jangka panjang, (4) Penggunaan praktik terbaik yang tepat oleh petani dan penggilingan, (5) Tanggung jawab lingkungan dan konservasi sumber daya alam dan keanekaragaman hayati, (6) Pertimbangan karyawan yang bertanggung jawab, dan individu dan masyarakat yang terkena dampak petani dan pabrik, (7) Pengembangan penanaman baru yang bertanggung jawab, dan (8) Komitmen untuk terus meningkatkan bidang kegiatan utama (RSPO., 2013).

Total luas yang telah disertifikasi oleh RSPO pada tahun 2017 secara keseluruhan adalah 1.719 .606 hektar. Berdasarkan data RSPO, terdapat 139.123 petani kecil mandiri dengan luas lahan bersertifikat333.345 hektare. petani kecil mandiri di Indonesia, telah menerima 111.816 sertifikasi dengan luas 190.064 hektare per 30 Juni 2017. Hingga 30 November 2017, ada tambahan 10 kelompok petani kecil mandiri yang memperoleh 
sertifikat RSPO, yang tersebar di Riau, Jambi, Kalimantan Tengah, Sumatera Utara, dan Sumatera Selatan. Total luas 4.358 hektar dengan 1.761 petani (Mongabay, 2017).

Selanjutnya, Indonesian Sustainable Palm Oil (ISPO) telah diakomodasi melalui Peraturan Menteri Pertanian Nomor 11 Tahun 2015. Melalui kebijakan ini, perusahaan perkebunan swasta dan negara diharuskan memiliki sertifikasi ini, sementara perkebunan mandiri masih bersifat sukarela di ISPO. Implementasi ISPO telah dimulai sejak 2011. Capaian ISPO tersebut dijelaskan oleh Komisi ISPO yang menerbitkan sebanyak 502 Sertifikat ISPO yang terdiri dari 493 perusahaan, 5 Koperasi Swadaya, dan 4 KUD Plasma. Sebanyak 502 sertifikat mencakup total luas $4.115 .434 \mathrm{Ha}$, dengan pabrik produksi seluas $2.765 .569 \mathrm{Ha}$, total produksi TBS 52.209.749 ton/ tahun dan CPO 11.567 .779 ton / tahun, dan produktivitas 18,81 ton / ha. (Beritasatu, 2019).

Sertifikasi RSPO dan ISPO ini tidak secara langsung menyelesaikan masalah tata kelola hutan di Indonesia. Namun, sertifikasi ini diperlukan untuk mengurangi dampak negatif dari pengembangan perkebunan kelapa sawit bagi masyarakat dan ekosistem sekitarnya. Penelitian dari Carlson et al. (2018) mengenai dampak RSPO terhadap deforestasi dan kebakaran di Indonesia menunjukkan bahwa sertifikasi RSPO memberikan indikator untuk memandu pelanggan menuju pembelian minyak sawit yang terkait dengan hilangnya tutupan pohon tinggi dan hutan primer yang lebih rendah baru-baru ini, serta insiden kebakaran. Mereka menemukan bahwa deforestasi yang lebih rendah yang terkandung dalam produk bersertifikat sebagian besar dihasilkan dari sertifikasi yang condong ke perkebunan dengan sedikit hutan yang tersisa. Dampak signifikan dari sertifikasi deforestasi menunjukkan bahwa tingkat sertifikasi yang lebih tinggi dapat menghasilkan perlindungan hutan yang lebih besar.

Kemudian, tanggung jawab perusahaan masyarakat dan lingkungan dalam tata kelola hutan dilakukan dalam bentuk rehabilitasi dan konservasi hutan, serta restorasi kawasan gambut. Hal ini dapat dilakukan oleh perusahaan sebagai implementasi dari tanggung jawab sosial perusahaan (CSR). PT SMART Tbk (SMART) berkomitmen melindungi hutan High Carbon Stock (HCS) dan High Conservation Value (HCV) seluas 9.457 hektar (Tbk., 2019). Selanjutnya, PT Agro Lestari Mandiri (PT AMNL) di Kalimantan Barat menggarap proyek gambut seluas 2.626,17 hektar (Tbk., 2016). Rehabilitasi gambut ini merupakan bagian dari keterlibatan dan kepedulian perusahaan terhadap lingkungan akibat dampak eksplorasi perkebunannya.

Namun, tentu saja peran korporasi ini dalam pengelolaan hutan di Indonesia masih minim dibandingkan kerusakan yang ditimbulkannya. Namun, ini merupakan optimisme bagi tata kelola hutan lestari, jika kegiatan perusahaan didukung oleh pengawasan intensif dari pemerintah, $\mathrm{CSO}$, dan masyarakat. Pemberdayaan berbagai pemangku kepentingan dalam tata kelola hutan akan mampu menghimpun energi dan sumber daya. Hal ini sesuai dengan prinsip pemerintahan partisipatif menurut Heinelt dalam Grote, J. R., \& Gbikpi (2002), yaitu bersama-sama dengan "empowerment" dan "enabling". Keterlibatan multi-aktor dengan pembagian peran dan tanggung jawab, keterbukaan, dan koordinasi sudah mulai dilakukan dalam tata kelola hutan di Indonesia.

\section{KESIMPULAN}

Tata hutan seharusnya tidak hanya menjadi tanggung jawab pemerintah, tetapi merupakan hasil kerja sama dengan berbagai pihak. Hal ini dibuktikan dengan tata kelola kehutanan di Indonesia pasca reformasi yang lebih menekankan pada paradigma partisipatif. Partisipasi dari multi stakeholder seperti masyarakat, masyarakat adat, aliansi LSM, dan korporasi dapat membangun sinergi dan sumber daya yang ada dalam mewujudkan tata kelola hutan lestari. Masyarakat dan masyarakat adat kini diberikan hak untuk mengelola hutan dengan diakui secara hukum oleh Pemerintah. Sementara itu, aliansi LSM berhasil menjadi intermediasi yang berkepentingan melalui perannya dalam melakukan advokasi kebijakan, pengawasan dan mendukung upaya penegakan hukum terhadap segala bentuk pelanggaran pengelolaan hutan. Peran CSO di tingkat lokal dan nasional juga berperan dalam penyelesaian konflik hutan melalui jejaring dengan berbagai pihak. Terakhir, pihak swasta memiliki tanggung jawab terhadap lingkungan di sekitar wilayah operasionalnya. Sertifikasi usaha perkebunan, rehabilitasi hutan, dan CSR merupakan bentuk komitmen perusahaan terhadap tata kelola hutan lestari di Indonesia.

\section{REFERENSI}

Agung, P., Galudra, G., Van Noordwijk, M., \& Maryani, R. (2014). Reform or reversal: the impact of REDD+ readiness on forest governance in Indonesia. Climate Policy, 14(6), 748768. https://doi.org/10.1080/14693062.2014.941317

Asihing, K. (2014). Actor, Interest and Conflict in Sustainable Mangrove Forest Management-A Case from Indonesia. International Journal of Marine Science, 4(16), 150-159. https://doi.org/10.5376/ijms.2014.04.0016

Astuti, R., \& McGregor, A. (2015). Responding to the green economy: how REDD+ and the One Map Initiative are transforming forest governance in Indonesia. Third World Quarterly, 36(12), 2273-2293. https://doi.org/10.1080/01436597.2015.1082422

Berg, B. L. (2001). Qualitative research methods for the social sciences 4thed. Allyn \& Bacon.

Beritasatu. (2019, April 22). Implementasi Percepatan ISPO Capai 502 Sertifikat 4,115 Juta Ha. Retrieved from https:/id.beritasatu.com/home/implementasi-percepatanispo-capai-502-sertifikat-4115-juta-ha/187058

Bowler, D. E., Buyung-Ali, L. M., Healey, J. R., Jones, J. P. G., Knight, T. M., \& Pullin, A. S. (2012). Does community forest Management provide global environmental benefits and improve local welfare? Frontiers in Ecology and the Environment, 10(1), 29-36. https://doi.org/10.1890/110040

Bryman, A. (2012). Social Research Methods Fourth Edition. New York: Oxford University Press Inc.

Bullinger, C., \& Haug, M. (2012). In and Out of the Forest: Decentralisation and Recentralisation of Forest Governance in East Kalimantan, Indonesia. Austrian Journal of South-East Asian Studies / Österreichische Zeitschrift Für Südostasienwissenschaften, 5, 243-262. Retrieved from http://search.ebscohost.com/login.aspx?direct=true\& $\& d b=a 9$ h\& $\&$ AN=84941645\& $\&$ site=ehost-live

Carlson, K. M., Heilmayr, R., Gibbs, H. K., Noojipady, P., Burns, D. N., Morton, D. C., ... Kremen, C. (2018). Effect of oil palm sustainability certification on deforestation and fire in 
Indonesia. Proceedings of the National Academy of Sciences of the United States of America, 115(1), 121-126. https://doi.org/10.1073/pnas.1704728114

Creswell, J. W. (2014). Research Design: Qualitative, Quantitative, and Mixed Methods Approaches 4th Ed. Los Angeles, London, New Delhi, Singapore, and Washington DC: SAGE Publications, Inc.

Dewi, I. N. (2018). Kemiskinan Masyarakat Sekitar Hutan dan Program Perhutanan Sosial (Poverty of the Community Around the Forest and the Social Forestry Program). Info Teknis EBONI, 15(2), 65-77.

Firdaus, A. Y. (2018). Panduan Praktis Penerapan Kebijakan Perhutanan Sosial: Kerangka Pencepatan Reformasi Tenurial Hutan. Bogor: CIFOR.

Fisher, L. A., Kim, Y. S., Latifah, S., \& Makarom, M. (2017). Managing forest conflicts: Perspectives of Indonesia's forest management unit directors. Forest and Society, 1(1), 8-26. https://doi.org/10.24259/fs.vlil.772

FORCLIME. (2016). Mendukung Resolusi Konflik Kehutanan di Indonesia melalui Mediasi Pengalaman proses multi-pihak pada tingkat lokal dan nasional di Kalimantan. Retrieved from https:/www.forclime.org/documents/Brochure/Bahasa/Co nflict resolution_GIZ-WGT_Bah.pdf

Forest, E. on the. (2016). KLHK harus melakukan penegakan hukum terhadap 49 Korporasi. Retrieved from https://www.eyesontheforest.or.id/news/klhk-harusmelakukan-penegakan-hukum-terhadap-49-korporasi

Forestry, M. of E. and. (2018). Status Hutandan Kehutanan Indonesia 2018. Jakarta: Ministry of Environment and Forestry.

Fröhlich, J., \& Knieling, J. (n.d.). 2013 Climate change governance. Springer, Berlin, Heidelberg.

Fung, A \& Wright, E. (eds. . (2003). Deepening Democracy: Institutional Innovations in Empowered Participatory Governance: The Real Utopias Project IV. London: Verso.

Gallemore, C., Di Gregorio, M., Moeliono, M., Brockhaus, M., \& Dini Prasti, R. H. (2015). This is a repository copy of Transaction costs, power, and multi-level forest governance in Transaction Costs, Power, and Multi-Level Forest Governance in Indonesia. Retrieved from

http://eprints.whiterose.ac.uk/86165/\%0Ahttp://creativeco mmons.org/licenses/by-ncnd/4.0/\%0Ahttps://eprints.whiterose.ac.uk/

Grote, J. R., \& Gbikpi, B. (2002). Participatory governance. Political and Societal Implications. Opladen: Leske+ Budrich.

Hein, J., \& Faust, H. (2014). Conservation, REDD+ and the struggle for land in Jambi, Indonesia. Pacific Geographies, 41, 20-25.

Heinelt, H. (2010). Governing modern societies: towards participatory governance. Routledge.

Houghton, C., Murphy, K., Shaw, D., \& Casey, D. (2015). Qualitative case study data analysis: An example from practice. Nurse Researcher, 22(5), 8-12. https://doi.org/10.7748/nr.22.5.8.el307

HuMa. (2018). Laporan Perkumpulan Huma 2018 Jurus Tandur. Jakarta: Perkumpulan Huma Indonesia.

Jessop, R. (2003). Governance, Governance Failure, and MetaGovernance. (November), 1-24.

Kooiman, J. (2003). Governing as Governance. Sage.
Mongabay. (2017, April 21). Ketika RSPO Dorong Perluasan Sertifikasi Kebun Sawit Petani Kecil. Retrieved from https://www.mongabay.co.id/2017/12/05/ketika-rspodorong-perluasan-sertifikasi-kebun-sawit-petani-kecil/

Mongabay. (2019, April 21). Penegakan Hukum Bidang Kehutanan. Retrieved from https://www.mongabay.co.id/penegakanhukum-bidang-kehutanan/

Monkelbaan, J. (2019). Governance for the Sustainabel Development Goals. Singapore: Springer Singapore.

Mulyani, M., \& Jepson, P. (2013). REDD+ and forest governance in Indonesia: a multistakeholder study of perceived challenges and opportunities. The Journal of Environment \& Development, 22(3), 261-283.

Nath, T. K., Jashimuddin, M., \& Inoue, M. (2016). Communitybased forest management (CBFM) in Bangladesh (Vol. 22). Switzerland: Springer.

Robert W. Kates, Thomas M. Parris, and A. A. L. (2005). Editorial-What Is Sustainable Development? Goals, Indicators, Values, and Practice. Environment: Science and Policy for Sustainable Development, 47(3), 8-21. Retrieved from http://www.cepn-parisl3.fr/epog/wpcontent/uploads/2016/01/CONSOLO_Kates-et-al.pdf

RSPO. (2013). Principles and Criteria for the Production of Sustainable Palm Oil 2013.

Sachs, J. D. (2012). From millennium development goals to sustainable development goals. The Lancet, 379(9832), 2206221l. https://doi.org/10.1016/S0140-6736(12)60685-0

Sahide, M. A. K., Supratman, S., Maryudi, A., Kim, Y. S., \& Giessen, L. (2016). Decentralisation policy as recentralisation strategy: forest management units and community forestry in Indonesia. International Forestry Review, 18(1), 78-95.

Saturi, S. (2012, April 11). Koalisi NGO: Presiden Harus Selesaikan Kasus Pulau Padang. Retrieved from https://www.mongabay.co.id/2012/06/29/koalisi-ngopresiden-harus-selesaikan-kasus-pulau-padang/

SETAPAK. (2018, April 11). SETAPAK Partner Contributes in Pushing for Transformation of the Management for Forest and Land in 14 Provinces. Retrieved from https://programsetapak.org/en/setapak-pers/setapakpartner-contributes-in-pushing-for-transformation-ofthe-management-for-forest-and-land-in-14-provinces/

Tbk., S. (2016, April 11). Mencegah kebakaran hutan di Indonesia dalam jangka panjang: berita terbaru Proyek Rehabilitasi Ekosistem Lahan Gambut PT SMART di Kalimantan Barat.

Tbk., S. (2019, April 11). Konservasi Hutan. Retrieved from https://www.smart-tbk.com/berkelanjutan/konservasihutan/

Wollenberg, E., Moeliono, M., Limberg, G., Iwan, R., Rhee, S., \& Sudana, M. (2006). Between state and society: Local governance of forests in Malinau, Indonesia. Forest Policy and Economics, $\quad$ 8(4), 421-433. https://doi.org/10.1016/j.forpol.2005.08.012

WWF. (2009, March 1). Hutan Indonesia: Penyerap atai Pelepas Emisi Gas Rumah Kaca? Retrieved from https://d2d2tbl5kqhejt.cloudfront.net/downloads/lembar_ fakta_deforestasi_tanpa_foto.pdf

Yasmi, Y, Guernier, J., Colfer, C. J. P., \& Guenier, J. (2009). Positive and negative aspects of forestry conflict: lessons 
from a decentralized forest management in Indonesia Aspects positifs et négatifs des conflits forestiers: leçons d'une gestion décentralisée des forêts en Indonésie Aspectos positivos y negativos. International Forestry Review, 11(1), 98-110.

Yasmi, Yurdi, \& Schanz, H. (2010). Managing conflict escalation in forestry: Logging versus local community interests in Baru Pelepat village, Sumatra, Indonesia. International Journal of Biodiversity Science, Ecosystem Services and Management, $\quad 6(1-2), \quad 43-51$. https://doi.org/10.1080/21513732.2010.509583 